\title{
ФИНАНСОВАЯ ГРАМОТНОСТЬ НАСЕЛЕНИЯ В ПЕРИОД ЦИФРОВОЙ ЭКОНОМИКИ
}

Коркин Р.И. ФГБОУ ВО «Санкт-Петербургский государственный университет гражданской авиации», г. Санкт-Петербург

Статья посвящена исследованию финансовой грамотности в период цифровизации и современных технологий в экономике. Отдельное внимание уделено определению «финансовая грамотность», а также критериям финансово грамотных людей. Полученные результаты в настоящей статье позволили автору сформулировать рекомендации по выбору эффективных направлений финансового просвещения населения, методик, способов оценки и контроля за этими процессами.

Ключевые слова: финансовая грамотность, цифровая экономика, деньги, доход, учет, сбережения, финансовая система.

Изменения в мировой экономике на протяжении последних лет наметили ряд преобразований и в нашей стране, в частности, в разработки и принятии со стороны органов государственной власти - стратегий и программ для развития информационного общества в Российской Федерации

Так в июле 2017 года Правительством РФ была утверждена программа «Цифровая экономика РФ», которая направлена на повышение благосостояния и качества жизни граждан путем повышения доступности и качества товаров и услуг, произведенных в цифровой экономике с использованием современных цифровых технологий, повышения степени информированности и цифровой грамотности, а также безопасности как внутри страны, так и за ее пределами [5].

С использованием цифровых технологий меняется повседневная жизнь человека, производственные отношения, возникают новые требования к коммуникациям, вычислительным мощностям, информационным системам и сервисам. Все это можно охарактеризовать 3-мя составляющими факторами:

1) Роботизация и искусственный интеллект - человека будет заменять робот и инновационные технологии - профессии кондуктора (используются гаджеты и устройства для оплаты проезда) и гида-экскурсовода (его заменяет аудиогид) уже исчезают, как исчезли работники телеграфа.

2) Дистанционное обслуживание - касается не только образовательных и банковских услуг, служб доставки и такси, но и новых направлений, таких как телемедицина.

3) Скорость обработки данных - моментальные или максимальные сжатые сроки анализа и передачи информации для последующего использования. Сервис Яндекс Переводчик - моментальный онлайн перевод 
текста на иностранный язык, Моментальная система межбанковских денежных платежей или новая услуга банков «Ипотека за 1 час».

Использование «цифровизации и диджитализации» не обошло личные финансы населения и финансовые институты общества. Проведение политики по внедрению современных технологий во многие сферы жизни общества и повышения уровня финансовой грамотности жителей страны, с одной стороны закладывает основу стабильного развития российской экономики в целом, с другой стороны определяет умение и способность достигать личного финансового успеха, повышает возможность благосостояния отдельного человека

Органами власти в 2011 году разработана и введена в действие концепция и запуск программы «Содействие повышению уровня финансовой грамотности населения и развитию финансового образования в Российской Федерации». В настоящий период разработана и принята «Национальная стратегия повышения финансовой грамотности», рассчитанная на 2017-2023 гг.[4]. В указанной стратегии повышения финансовой грамотности (далее - Стратегия) содержатся приоритеты и методы эффективного достижения и решения органов государственной власти в регулированию отношений, возникающих в процессе повышения финансовой грамотности населения, внедрение в образовательный процесс систему знаний об управлении личными финансами, а также информирование в сфере защиты прав потребителей финансовых услуг на среднесрочный период. Данная Стратегия определяет повышение финграмотности как один из главных критериев повышения конкурентоспособности отечественной экономики. И хоть ведется работа и прослеживаются шаги по повышению уровня финансовой образованности нашего общества, в том числе и со стороны государства, уровень финансовой культуры среди россиян остается крайне низкими и требует систематической и скоординированной деятельности.

Финансовая грамотность - разумная (рациональная) способность управлять денежными средствами от имеющихся источников дохода.

Установки и практические навыки финансово просвещенных грамотных людей:

1. Составляют бюджет (доходы и расходы).

2. Имеют долгосрочный финансовый и инвестиционный план.

3. Используют множественные источники дохода, а не один.

4. Имеют «финансовую подушку безопасности» - «резервный фонд»и могут использовать средства на непредвиденные расходы.

5. Знают, что такое страхование и пользуются им.

6. Используют льготы и налоговые вычеты от государств [1].

Основные причины низкой финансовой грамотности россиян и их три получаются, во-первых: отсутствием нормативно-правовой базы со стороны органов государственной власти по повышению финансовой грамотности, втретьих отсутствием методических программ и систематической работы по повышению финансовой грамотности среди различных слоев населения и 
третье - отсутствием информации и небольшим количеством обучающих платформ по изучению финграмотности, а также нежеланием общества просвещаться и образовываться учету личных финансов [2].

Широкое внедрение цифровых технологий в повседневную жизнь изменяет характер товарно-денежных отношений, в которые вступают субъекты экономики. Все больше покупок оплачивается без использования наличных денег, а путем уже не только пластиковых карт, а еще с помощью гаджетов - смартфонов, смарт-часов, браслетов, колец и др., появляются новые финансовые продукты, и даже новые формы денег, такие как криптовалюты [3]. С другой стороны, новые технологии - это новые вызовы, новые риски, новые угрозы. На ниве стремительного развития цифровизации, активизировались и представители киберпреступности, которые используют новейшие инструменты, в том, числе и социальную инженерию: всевозможные хакеры, мошенники, аферисты, «схематворцы». Далее хочу представить аналитические данные банка «Тинькофф», который провел исследование мошеннических схем за 2019 год: Возраст обманутых граждан до 33 лет и старше 68 лет, в 83 \% случаев мошенники звонят своим жертвам по телефону и представляются службой безопасности банка, в 17\% - происходит завлечение через социальные сети и мессенджеры, а также через рассылку электронной почты. Чаще всего обманные действия в Интернете выражаются в предложениях заработка и подработки, вложениях в «мегапроекты», через онлайн-покупки с подменой формы на оплату, взломом аккуантов в социальных сетях с просьбой срочной помощи, через «липовые сайты» с тотализаторами, принятием ставок и проведением лотерей и др.

Хочется отметить, что снижение рисков по потере личных финансов граждан будет происходить, если обыватели начнут изучать просвещаться финансовой грамотности и применять ее на практике. Указанные действия помогут обеспечить доверие к органам государственной власти и местного самоуправления, финансовой и банковской системе, общественным организациям, улучшить уровень благосостояния населения и укрепить национальную безопасность страны.

\section{Список литературы}

1. Коркин Р.И. Финансовая грамотность домашних хозяйств в современной России // «Цифровая экономика и финансовые кибертехнологии: проблемы и перспективы». Смирновский чтения -2019 (21 марта 2019г. СанктПетербург) - Санкт-Петербург: МБИ, 2019. - С. 65-67

2. Коркин Р.И. Актуальность финансовой грамотности домашних хозяйств в современной России // Условия социально-экономического развития общества: история и современность. Материалы международной научнопрактической конференции 14 Ямбургские чтения. - Кингисепп, 2019 с.26-27.

3. Ромашкин T.В. Развитие финансовой грамотности в эпоху цифровизации // Педагогический опыт: от теории к практике: Сборник 
материалов III международной научно-практической конференции (02.12.2017 Чебоксары). - Чебоксары: ЦНС «Интерактивплюс», 2017.С.51-53.

4. Распоряжение Правительства РФ «Национальная программа «Цифровая экономика Российской Федерации. Режим доступа: https://digital.gov.ru/ (дата обращения: март 2020 года).

5. Распоряжение Правительства РФ от 25.09.2017 № 2039-р «Об утверждении Стратегии повышения финансовой грамотности 2017-2023 годы». Режим доступа: http://static.government.ru (дата обращения: март 2020). 